\title{
Three allele combinations associated with Multiple Sclerosis
} Olga O Favorova*1,2, Alexander V Favorov³, Alexey N Boiko ${ }^{4}$, Timofey V Andreewski², Marina A Sudomoina ${ }^{1,2}$, Alexey D Alekseenkov², Olga G Kulakova ${ }^{1}$, Eugenyi I Gusev ${ }^{4}$, Giovanni Parmigiani ${ }^{5}$ and Michael F Ochs ${ }^{6}$

Address: ${ }^{1}$ Department of Molecular Biology and Medical Biotechnology, Russian State Medical University, 15 3d Cherepkovskaya ul., Moscow 121552, Russia, ${ }^{2}$ Cardiology Research Center, 15 3d Cherepkovskaya ul., Moscow 121552, Russia, ${ }^{3}$ Bioinformatics Laboratory, GosNIIGenetika, 1 1st Dorozhny pr., Moscow 117545, Russia, ${ }^{4}$ Department of Neurology and Neurosurgery, Russian State Medical University, 1 Ostrovitianova ul., Moscow 117997, Russia, ${ }^{5}$ Departments of Oncology, Pathology and Biostatistics, Johns Hopkins University, 550 North Broadway, s. 1103 , Baltimore, Maryland 21205, USA and ${ }^{6}$ Fox Chase Cancer Center, 333 Cottman Avenue, Philadelphia, Pennsylvania 19111, USA

Email: Olga O Favorova* - olga_favorova@mail.ru; Alexander V Favorov - favorov@sensi.org; Alexey N Boiko - boikoa@online.ru; Timofey V Andreewski - timofey@cardio.ru; Marina A Sudomoina - sudom@cardio.ru; Alexey D Alekseenkov - mol-bio@cardio.ru; Olga G Kulakova - mol-bio@cardio.ru; Eugenyi I Gusev - biokoa@online.ru; Giovanni Parmigiani - gp@jhu.edu; Michael F Ochs - m_ochs@fccc.edu

* Corresponding author

Published: 26 July 2006

BMC Medical Genetics 2006, 7:63 doi:10.1 186/147/-2350-7-63
Received: 17 March 2006

Accepted: 26 July 2006

This article is available from: http://www.biomedcentral.com/I47I-2350/7/63

(c) 2006 Favorova et al; licensee BioMed Central Ltd.

This is an Open Access article distributed under the terms of the Creative Commons Attribution License (http://creativecommons.org/licenses/by/2.0), which permits unrestricted use, distribution, and reproduction in any medium, provided the original work is properly cited.

\begin{abstract}
Background: Multiple sclerosis (MS) is an immune-mediated disease of polygenic etiology. Dissection of its genetic background is a complex problem, because of the combinatorial possibilities of gene-gene interactions. As genotyping methods improve throughput, approaches that can explore multigene interactions appropriately should lead to improved understanding of MS.

Methods: 286 unrelated patients with definite MS and 362 unrelated healthy controls of Russian descent were genotyped at polymorphic loci (including SNPs, repeat polymorphisms, and an insertion/deletion) of the DRBI, TNF, LT, TGF $\beta$ I, CCR5 and CTLA4 genes and TNFa and TNFb microsatellites. Each allele carriership in patients and controls was compared by Fisher's exact test, and disease-associated combinations of alleles in the data set were sought using a Bayesian Markov chain Monte Carlo-based method recently developed by our group.
\end{abstract}

Results: We identified two previously unknown MS-associated tri-allelic combinations:

$-509 T G F / * C$, DRBI*I8(3), CTLA4*G and $-238 T N F * B 1,-308 T N F * A 2, C T L A 4 * G$, which perfectly separate MS cases from controls, at least in the present sample. The previously described $D R B|*| 5(2)$ allele, the microsatellite TNFa9 allele and the biallelic combination CCR5 32 , DRBI*04 were also reidentified as MS-associated.

Conclusion: These results represent an independent validation of MS association with $D R B I * I 5(2)$ and TNFa9 in Russians and are the first to find the interplay of three loci in conferring susceptibility to MS. They demonstrate the efficacy of our approach for the identification of complex-disease-associated combinations of alleles. 


\section{Background}

Investigation of polygenic human diseases, which arise from the combined contribution of multiple independently acting and/or interacting polymorphic genes, remains a great challenge [1-3]. A common constituent of the complexity that underlies the susceptibility to polygenic diseases is heterogeneity [3,4]. MS [MIM 126200] is an immune-mediated hereditary disease [5,6], and can be considered as a prototype for polygenic human diseases [4]. The results of linkage-based whole genome screen studies $[7,8]$ and a global meta-analysis $[9,10]$ document the concept that MS is the result of the interaction of several genes. The effects of individual genes are small or modest, making association studies more informative than others because of their greater statistical power $[1,11]$. Association testing is extensively employed in candidate-gene studies, which are usually conducted in population-based case-control studies. To date, the HLA class II DRB1*1501/DQA1*0102/DQB1*0602 (DR2) haplotype is the only region repeatedly confirmed as being associated with $\mathrm{MS}$ in most Caucasians $[5,10]$. Other candidate genes for MS predisposition studies have been selected mainly because their encoded proteins are involved in autoimmune pathogenesis. These include genes for immunorelevant molecules such as cytokines, cytokine receptors, immunoglobulins, T-cell receptors and specific adapter protein, potential autoantigens of the myelin sheath, ICAM1, and others [12].

Some studies searched for candidate gene combinations as MS risk factors; however, these studies have not yet extended beyond MS associations with alleles of each candidate gene coupled with HLA DRB1 alleles [13-19]. To examine the possibility that the combined effect of definite genes is a risk factor for a polygenic disease, it is necessary to explore a massive number of potential combinations of allelic variants identified at candidategene polymorphic loci. This number grows exponentially with the number of candidate variants that may interact, causing computational and statistical restrictions on the use of standard enumerational methodologies. In a recent paper [20], we described a novel algorithm based on Markov chain Monte Carlo exploration using a Bayesian statistical basis, APSampler, which allows the exploration of genotypes tied to phenotypic trait levels to identify possible combinations of allelic variants at multiple loci that could affect disease development. The aim of this study is to simultaneously examine multiple candidate genes in single groups of unrelated MS patients and healthy unrelated controls, all of Russian descent, and to search for disease-associated combinations of allelic variants at multiple loci using our novel nonparametric methodology [20].

\section{Methods \\ Subjects and DNA samples}

Two hundred eighty six unrelated patients (110 men and 176 women, mean age $33 \pm 12$ years) had a diagnosis of MS [21]. Of these 187 had a relapsing-remitting MS course, 39 a primary progressive MS course, and 60 were secondary progressive. The mean age at onset was $23 \pm 9$ years. Three hundred sixty-two unrelated controls (203 men and 159 women, mean age $30 \pm 11$ years) were studied. All controls were free of acute or chronic internal and neurological diseases as determined by physical examinations. All subjects were living in the Moscow area; both their parents were ethnic Russians. Informed consent to the study was obtained from all participants and was approved by the local Ethical Committee. Blood was adjusted to $25 \mathrm{mM}$ EDTA. Genomic DNA was isolated from $5 \mathrm{~mL}$ of peripheral blood by phenol-chloroform extraction using standard procedures.

\section{Genotyping}

Investigated polymorphic loci (including SNPs, repeat polymorphisms, and one insertion/deletion) and the numbers of genotyped MS patients and controls for each marker are presented in Table 1.

\section{HLA DRB I gene}

For genomic typing of the DRB1 gene, a sequence-specific primer (PCR-SSP) technique was used. The two-step PCR allowed amplification of all known DRB1 alleles and their separation into groups corresponding to the specificities from DR1 to DR18 [22].

\section{TNFa and TNFb microsatellites}

For a length polymorphism analysis of $(\mathrm{AC})_{\mathrm{n}}$ and $(\mathrm{TC})_{\mathrm{n}}$ microsatellites, designated as TNFa and TNFb, which are located $3.5 \mathrm{~kb}$ upstream of the LT gene, nested PCR was used. The second PCR was carried out in the presence of $\left[\alpha-{ }^{32} \mathrm{P}\right] \mathrm{dATP}$, then PCR products were treated by the Klenow fragment of DNA polymerase I and electrophoresed in an $8 \%$ polyacrylamide sequencing gel [23].

\section{SNPs in TNF gene}

Genotyping of the $-238 \mathrm{~A} \rightarrow \mathrm{G}$ polymorphism was performed by analysis of restriction fragment length polymorphism of PCR products (PCR-RFLP method). PCR amplification was carried out using the exactly homologous forward primer, while the reverse primer contained two sequence mismatches, which made it possible to evaluate mutation status using the restriction enzyme Bam HI [24]. Analysis of the $-308 \mathrm{G} \rightarrow \mathrm{A}$ polymorphism was performed by PCR-SSP [25]. For genotyping of the $-376 \mathrm{~A} \rightarrow \mathrm{G}$ polymorphism, the PCR-SSP method was also used. The forward primers are 5'-CTT TTT CCT GCA TCC TGT CTG GAA A-3' for -376A and 5'-CTT TTT CCT GCA TCC TGT CTG GAA G-3' for $-376 \mathrm{G}$, the common reverse primer was 
Table I: Polymorphous loci at or near genes of immune response included in the database

\begin{tabular}{|c|c|c|c|c|c|}
\hline Gene/marker & $\begin{array}{l}\text { Chromosome } \\
\text { localization }\end{array}$ & Polymorphism type* [refSNP ID]** & $\begin{array}{l}\text { Names of alleles } \\
\text { considered }\end{array}$ & $\begin{array}{l}\text { Method of analysis } \\
\text { (the restriction } \\
\text { endonuclease used) }\end{array}$ & $\begin{array}{c}\text { Numbers of } \\
\text { genotyped MS } \\
\text { patients/controls }\end{array}$ \\
\hline$D R B I$ & $6 p 21$ & $\begin{array}{c}\text { Allele groups corresponding to } \\
\text { serological specificities DRI- } \\
\text { DRI8(3) }\end{array}$ & $0 \mathrm{I}-18(3)[44]$ & PCR-SSP & $229 / 314$ \\
\hline Microsatellite TNFa & $6 p 21$ & $(\mathrm{AC})_{\mathrm{n}}$ & $\mathrm{al}-\mathrm{a} \mid 3[23]$ & Nested PCR & $121 / 103$ \\
\hline \multirow[t]{2}{*}{ Microsatellite TNFb } & $6 p 21$ & $(\mathrm{TC})_{\mathrm{n}}$ & bl-b7[23] & Nested PCR & $120 / 96$ \\
\hline & & SNP $-376 \mathrm{~A} \rightarrow \mathrm{G}[\mathrm{rs} \mid 800750]$ & $A, G$ & PCR-SSP & $202 / 146$ \\
\hline \multirow[t]{2}{*}{ TNF } & $6 p 21$ & SNP -308G $\rightarrow$ A [rs 1800629$]$ & $\mathrm{Al}, \mathrm{A} 2$ & PCR-SSP & $223 / 222$ \\
\hline & & SNP -238A $\rightarrow G$ [rs361525] & $\mathrm{BI}, \mathrm{B} 2$ & PCR-RFLP (BamHI) & $165 / 112$ \\
\hline \multirow[t]{4}{*}{$L T$} & $6 p 21$ & $\mathrm{SNP}+252 \mathrm{G} \rightarrow \mathrm{A}$ & $\mathrm{NI}, \mathrm{N} 2$ & PCR-RFLP (Ncol) & $205 / 150$ \\
\hline & & $\mathrm{SNP}+319 \mathrm{C} \rightarrow \mathrm{G}$ & $\mathrm{HI}, \mathrm{H} 2$ & PCR-RFLP (AspHI) & $202 / 147$ \\
\hline & & SNP -509C $\rightarrow$ T [rs I755I290] & $\mathrm{C}, \mathrm{T}$ & PCR-SSO & $119 / 295$ \\
\hline & & SNP +72 wild type $\rightarrow C$ insertion & wt, ins & & $198 / 340$ \\
\hline \multirow[t]{3}{*}{$T G F \beta I$} & $19 q 13$ & SNP $+869 \mathrm{~T} \rightarrow$ C (IOLeu $\rightarrow$ Pro $)$ & $\mathrm{T}, \mathrm{C}$ & & $150 / 248$ \\
\hline & & $\mathrm{SNP}+915 \mathrm{G} \rightarrow \mathrm{C}(25 \mathrm{Arg} \rightarrow$ Pro $)$ & G, C & & $157 / 248$ \\
\hline & & $\mathrm{SNP}+1632 \mathrm{C} \rightarrow \mathrm{T}(263 \mathrm{Thr} \rightarrow \| \mathrm{le})$ & C, T & & $178 / 109$ \\
\hline CCR5 & $3 p 21$ & Wild type $\rightarrow 32$ base pair deletion & wt, $\Delta 32$ & PCR & $221 / 355$ \\
\hline CTLA4 & $2 q 33$ & $\begin{array}{c}\mathrm{SNP}+49 \mathrm{~A} \rightarrow \mathrm{G}(17 \mathrm{Thr} \rightarrow \mathrm{Ala}) \\
{[\mathrm{rs} 23 \mathrm{I} 775]}\end{array}$ & $A, G$ & PCR-RFLP (BstEII) & $168 / 209$ \\
\hline
\end{tabular}

Abbreviations used: CCR5 - CC chemokine receptor 5 gene; CTLA4 - cytotoxic T-lymphocyte-associated protein 4 gene; DRBI - major histocompatibility complex class II DR $\beta$-chain gene I; LT - lymphotoxin $\alpha$ gene; TGF $\beta$ I - transforming growth factor $\beta$-I gene; TNF - tumor necrosis factor gene; PCR - polymerase chain reaction; RFLP - restriction fragment length polymorphism; SSO - sequence-specific oligonucleotides; SSP - sequence-specific primers; ins - insertion; wt - wild type.

* All positions of the SNPs are indicated relative to transcriptional start sites except CTLA4 SNP +49 , where +49 is the position from translational start site.

** RefSNP IDs (rs\#) are given for SNPs submitted in PubMed NCBI dbSNP.

5'-TTC TGT CTC GGT TTC TTC TCC ATC G-3'. These primers were constructed using free on-line software GeneFisher-Interactive PCR Primer Design [26]. PCR was performed in $10 \mu \mathrm{L}$ volumes containing 0.1 units of Taq polymerase (from SileksM, Moscow, Russia), $200 \mathrm{ng}$ of genomic DNA, 5 pmol of the reverse PCR primer, $5 \mathrm{pmol}$ of the sequence-specific PCR primer for allele A or 2.5 pmol of the sequence-specific PCR primer for allele $\mathrm{G}$, four dNTPs (each at $5 \mathrm{mM}$ ), $70 \mathrm{mM}$ Tris $\mathrm{HCl} \mathrm{pH} \mathrm{9.0,} 20$ $\mathrm{mM}\left(\mathrm{NH}_{4}\right)_{2} \mathrm{SO}_{4}, 0.025 \%$ Tween $20,0.025 \%$ NP-40, 1.0 $\mathrm{mM} \mathrm{MgCl}_{2}$. Thermocycling consisted of 35 cycles of $92^{\circ} \mathrm{C}$ for $60 \mathrm{~s}, 60^{\circ} \mathrm{C}$ for $90 \mathrm{~s}, 72^{\circ} \mathrm{C}$ for $90 \mathrm{~s}$. The resulting fragment length was $238 \mathrm{bp}$.

\section{SNPs in LT gene}

Genotyping of the $+252 \mathrm{G} \rightarrow \mathrm{A}$ and $+319 \mathrm{C} \rightarrow \mathrm{G}$ polymorphisms was performed by PCR-RFLP method. For analysis of the SNP $+252 \mathrm{G} \rightarrow \mathrm{A}$, PCR amplification was performed and the product aliquots were digested using the restriction enzyme NcoI[27]. In parallel, other aliquots of the same PCR products were digested using the restriction enzyme Alw21I $(A s p H I)$ for analysis of SNP $+319 \mathrm{C} \rightarrow \mathrm{G}$ [24].
SNPs in TGF $\beta$ I gene

For genotyping of five SNPs in the TGF $\beta 1$ gene, four PCR fragments were obtained (one PCR fragment was common for the SNP $+869 \mathrm{~T} \rightarrow \mathrm{C}(10 \mathrm{Leu} \rightarrow$ Pro $)$ and SNP $+915 \mathrm{G} \rightarrow \mathrm{C}(25 \mathrm{Arg} \rightarrow$ Pro $))$. Then resulting fragments were immobilized on Hybond-N+ membrane (Amersham Pharmacia Biotech) followed by hybridization with sequence-specific oligonucleotide probes (PCR-SSO method). PCR conditions, primers and probes were as those described in [28], hybridization procedure was modified according to [29] as follows. Prehybridization was performed for at least $2 \mathrm{~h}$ at $52^{\circ} \mathrm{C}$ in $3.0 \mathrm{M}$ tetramethylammonium chloride (TMAC), $50 \mathrm{mM}$ Tris $\mathrm{HCl} \mathrm{pH} \mathrm{8.0,}$ $2 \mathrm{mM}$ EDTA, $5 \times$ Denhardt's solution, $0.1 \%$ SDS, $100 \mathrm{ng} /$ $\mathrm{mL}$ heat-denatured herring sperm DNA and $10-20 \mathrm{pmol} /$ $\mathrm{mL}$ of unlabeled oligonucleotide probe specific for the other allele. Then $10-20 \mathrm{pmol} / \mathrm{mL}$ of $[\gamma-32 \mathrm{P}]$ ATP-labeled allele-specific oligonucleotide was added and hybridization was performed for at least $2 \mathrm{~h}$ at $52^{\circ} \mathrm{C}$. The membranes were washed at room temperature in $2 \times$ SSC for 30 min followed by $2 \times 15 \mathrm{~min}$ in $2 \times$ SSC, $0.1 \%$ SDS. Then the membranes were washed twice at $58^{\circ} \mathrm{C}$ in $3.0 \mathrm{M}$ TMAC, $50 \mathrm{mM}$ Tris $\mathrm{HCl} \mathrm{pH}$ 8.0, $2 \mathrm{mM}$ EDTA, 0.1\% SDS, rinsed in $2 \times$ SSC and autoradiographed. 


\section{2 base pair deletion in CCR5 gene}

CCR5 genomic typing was performed using one-step PCR with primers flanking the region of the 32-nucleotide deletion [30].

\section{SNP in CTLA4 gene}

Genotyping of SNP $+49 \mathrm{~A} \rightarrow \mathrm{G}$ in CTLA4 gene was performed by PCR-RFLP analysis using the restriction enzyme BstEII [31].

\section{Database}

The genotypes and personal data for all patients and controls were entered into a database, together with clinical characteristics for patients. Microsoft Visual FoxPro was used to develop a standalone database management system that was used for input and analysis of the data.

\section{Search algorithm}

We used the APSampler algorithm [20] that identifies combinations (patterns) of alleles at different loci that are potentially associated with a phenotypic trait. Here, we provide a brief description of the algorithm. The a posteriori probability for support of each pattern given the data is evaluated using a likelihood obtained from a battery of conditional rank sum statistics that insures that each pattern is evaluated after removing the effect of other patterns, as in a statistical adjustment for multiple regression. Each step of the algorithm is an update of a current set of allelic patterns by a variation of the Metropolis-Hastings algorithm [32,33]. The sets of patterns that receive high support from the data are stored as potential results. For each pattern, only those individuals that have all the pattern's alleles genotyped were considered. Thus the algorithm proceeded from incomplete genotypic information, temporarily omitting those individuals that cannot be unambiguously classified into the pattern carriers and non-carriers at a given step. The executable files for Win32 console and for FreeBSD, together with documentation, are available free to academic users (contact AVF or MFO).

In the current application to the MS case-control data, the prior probability that a locus has no effect on the phenotype was set to 0.99 . This favored $a$ priori the case in which each locus has no effect on phenotype, so that the search would not explore patterns with a very large number of alleles, which are unlikely to be reliably investigated in this data set. We looked for sets of 2 or 3 patterns.

\section{Statistical analysis}

To compare allelic distributions in MS patients and controls and to verify the APSampler's results, we used Fisher's exact test. The analysis was performed using the GraphPad InStat software package and original computer scripts under Microsoft Visual FoxPro. As a statistical control for systematic genotyping error and population strat- ification, the expected genotype proportions according to the Hardy-Weinberg equilibrium were calculated and compared to observed genotypes. For polymorphic DRB1 and TNFa loci, the $p$-values were corrected for the number of comparisons (13 in case of DRB1 allele groups and 12 in case of TNFa alleles) according to the Bonferroni method. The $p$-values and corrected $p$-values $\left(p_{\text {corr }}\right)$ were considered to be significant at a level smaller than 0.01. The odds ratio (OR) was calculated with a $95 \%$ confidence interval (CI).

For the haplotype frequency estimation, for the linkage disequilibrium test, and for the Hardy-Weinberg disequilibrium test, the population genetics data-analyzing software Arlequin (version 2.0) [34] was used. We considered a linkage disequilibrium or a Hardy-Weinberg disequilibrium to be significant when the $p$-value from the Arlequin output was less than or equal to 0.05 . For estimation of haplotype frequencies, the default parameters were used. To assess the significance of the APSampler-discovered patterns, we computed the Empirical Bayes false discovery rate, which is the estimated fraction of patterns unrelated to the phenotype among those that have a significance score as high or higher than the pattern reported [35]. The vector of disease labels was permuted in a balanced way by assigning the same number of diseased and healthy individuals to two groups generated by permutation. We repeated the permutation 100 times and examined all possible combinations with the same number of alleles as the pattern considered. For each permutation and each combination, we computed a test of association and counted the fraction of these tests that were larger than the observed test for the pattern.

\section{Results}

Individuals were genotyped at polymorphic loci at or near genes of the immune response situated at chromosomes 2, 3, 6 and 19 (Table 1). The allelic carriership (phenotypic frequency) in case of biallelic candidate loci (Figure 1) did not differ significantly in MS patients and controls. The allelic distributions of polymorphic candidate loci showed a positive association of MS with a carriership of allele group $D R B 1^{*} 15(2)$, corresponding to serological specificity DR15(2) $\left(p_{\text {corr }}<0.0001, \mathrm{OR}=3.1, \mathrm{CI}\right.$ is $\left.2.1-4.6\right)$ (Figure $2 \mathrm{~A}$ ), and with a carriership of a TNFa* 9 microsatellite allele $\left(p_{\text {corr }}<0.01, \mathrm{OR}=7.9, \mathrm{CI}\right.$ is $\left.1.8-35.0\right)$ (Figure $2 \mathrm{~B})$. The allelic distribution of the TNFb microsatellite, which is adjacent to TNFa, did not differ significantly in MS patients and controls (Figure 2C). It agreed with $\mathrm{TNFa} / \mathrm{TNFb}$ haplotype frequencies in patients and controls, which were estimated from genotype data via the population genetics data-analyzing software Arlequin version 2.00 [34]. The predisposing TNFa9 allele was part of three different haplotypes: TNFa9/TNFb1, TNFa9/TNFb4 and TNFa9/TNFb5 [see Additional File 1]. Both the HLA 

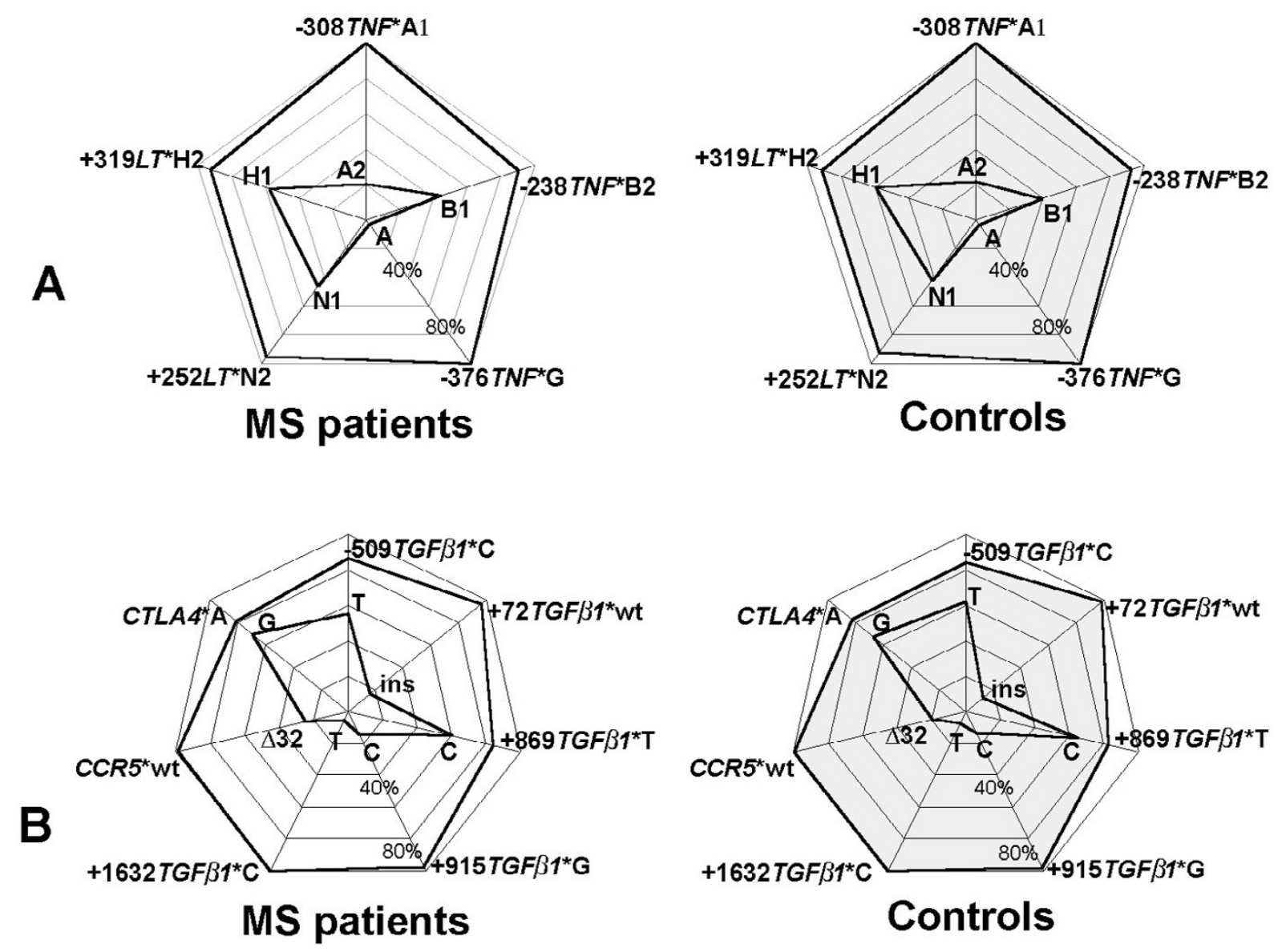

Figure I

Phenotypic frequencies (\%) of SNP alleles in Russian MS patients and healthy individuals. The numbers of typed individuals are given in Table I. A: TNF and LT gene polymorphic regions; B: TGF $\beta$ I, CCR5 and CTLA4 gene polymorphic regions. For each SNP, phenotypic frequencies of both alleles are shown on the same axis of a radar chart; thick lines join all common and all rare alleles of SNPs presented, and SNP allele names are indicated on the vertices. The same data are presented in Additional Table I [see Additional File 4].

class II DRB1 gene and the class III TNFa microsatellite map to $6 \mathrm{p} 21$ and were in linkage disequilibrium; however, the DRB1*15(2)/TNFa9 haplotype frequency estimated from genotype data by the Arlequin software did not exceed 1\% [see Additional File 2]. This suggested that DRB1 ${ }^{*} 15(2)$ and TNFa9 represented two independent MS-predisposing markers. The fact that no alleles of the tumor necrosis factor (TNF) and lymphotoxin $\alpha(L T)$ genes, also located at $6 \mathrm{p} 21$, differed significantly between MS patients and controls (see Figure 1A) correlated with the lack of strong linkage of TNF/LT haplotypes with DRB1*15(2) [see Additional File 3] and TNFa9 (not shown).

Application of the APSampler algorithm [20] identified five patterns that have a high probability of being associated with MS according to a multidimensional Wilcoxon- based criterion. All the patterns identified deal with carriership of alleles, without distinguishing homozygotes from heterozygotes. Two of the patterns were the single predisposing alleles DRB1*15(2) and TNFa9 discussed above, while the third pattern was a predisposing biallelic combination of CCR $5 \Delta 32$ with DRB $1{ }^{*} 04$, which was recently described for this data set $[15,20]$. Importantly, two new patterns comprising "trios" of allelic variants were also identified. The first pattern included the $\mathrm{C}$ allele of SNP - 509 of the transforming growth factor $\beta 1$ (TGF $\beta 1$ ) gene, DRB1*18(3), and the G allele of the cytotoxic Tlymphocyte antigen 4 (CTLA4) gene (trio 1). The second pattern included the alleles -238TNF*B1, -308TNF*A2 and again, CTLA $4^{*} \mathrm{G}$ (trio 2). Fisher's exact test gave $\mathrm{p}<$ 0.01 for the association of MS with both patterns, ORs were equal to 18.0 (CI 1.0-330) for trio 1 and 17.4 (CI 1.1-300) for trio 2 (Table 2). To assess the probability 


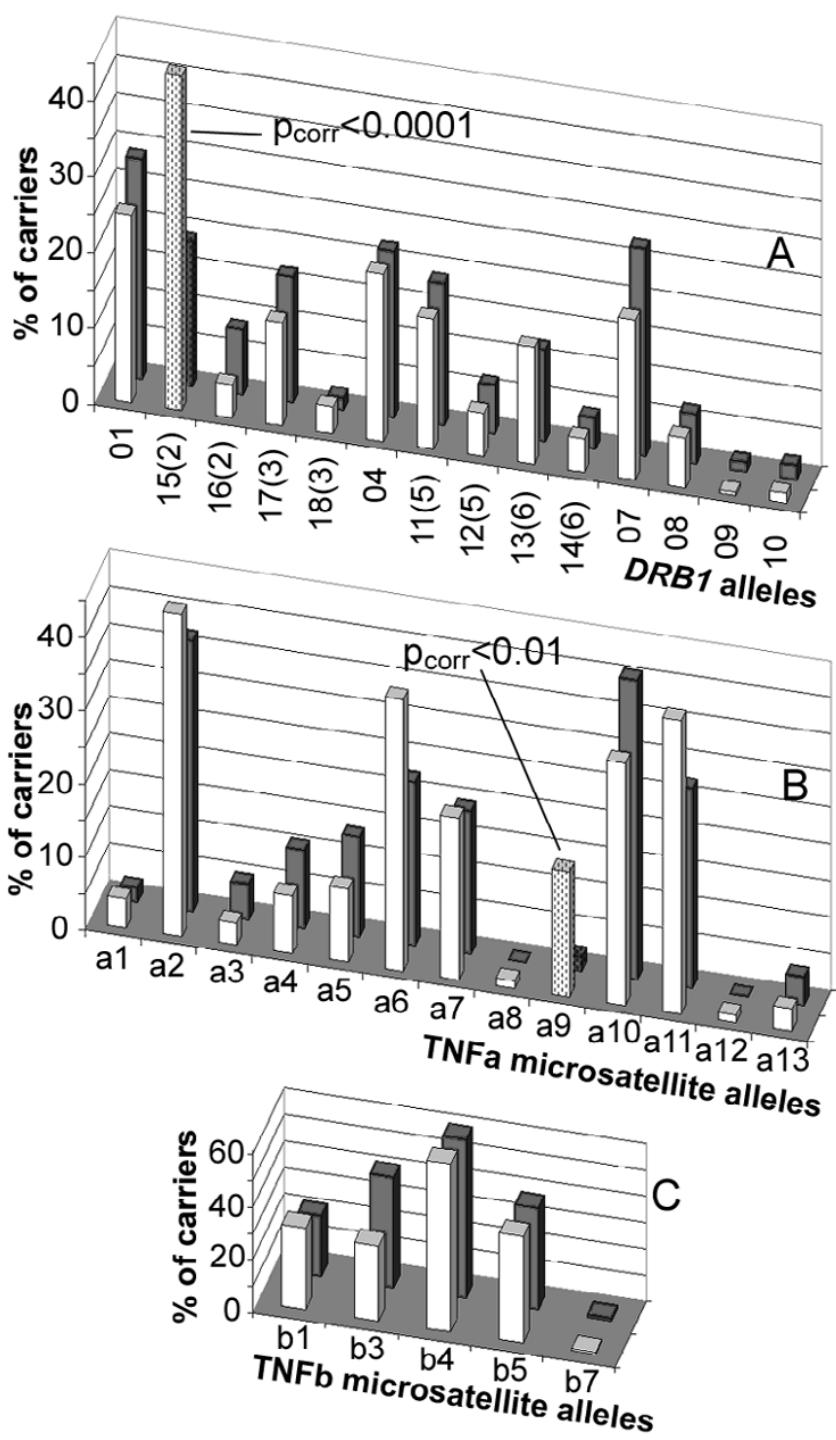

Figure 2

Phenotypic frequencies (\%) of some polymorphous HLA loci in the Russian population. MS patients are shown by white bars and healthy individuals are shown by grey bars. The numbers of typed individuals are given in Table I. A: HLA DRBI. B: TNFa microsatellite. C: TNFb microsatellite. For significant differences, $p_{\text {corr }}$ values are shown near the corresponding bars, which are shaded.

that the trio patterns found were truly associated with MS, we also computed the false discovery rate, which was less than 0.003 . The algorithm was intended to identify patterns as minimal allelic sets, in the sense that such a set provides stronger evidence of association with MS than any of its subsets. As shown above (Figures 1 and 2A), none of the alleles involved in the trios were an individual risk factor. For both trios, among individuals who have all the three alleles genotyped, the difference in phenotypic frequencies for two-element subsets between MS patients and healthy subjects was insignificant, with p-values always exceeding 0.025 (Table 2). So, both trios, which gain Fisher's test p-values less than 0.01 , were correctly identified as minimal MS-associated allelic sets. The fact that two alleles of the TNF gene were required to form trio 2 was in agreement with the data suggesting that TNF*B1 and $\mathrm{TNF}^{*} \mathrm{~A} 2$ are not parts of a single widespread haplotype [see Additional File 3].

\section{Discussion}

Based on the results presented, several (partially overlapping) subgroups may be identified in the common group of Russian MS patients, depending on carriership of distinct minimal patterns of susceptibility including one $(D R B 1 * 15(2)$ or TNFa9), two (CCR5 $332, D R B 1 * 04)$ and three $\left(-509 T G F \beta 1{ }^{*} \mathrm{C}, \quad D R B 1{ }^{*} 18(3), \quad C T L A 4^{*} \mathrm{G}\right.$ or 238TNF*B1,-308TNF*A2, CTLA4* ${ }^{*}$ ) alleles of candidate genes. These results are evidence of the genetic heterogeneity of MS.

MS associations with $D R B 1^{*} 15(2)$ and TNFa9 were previously identified in our studies of independent groups of ethnic Russians [36,37] and were replicated here for a new dataset of patients and control subjects. Thus, the HLA class II $D R B 1^{*} 15(2)$ is validated in this study as being associated with MS in Russians as in most other Caucasians. As follows from our data, DRB1*15(2) and TNFa9 represent two independent predisposing markers, in agreement with the proposal that two MS susceptibility loci exist within the MHC $[5,38]$.

In previous studies, identification of MS-predisposing combinations of allelic variants at multiple loci consisted in stratification of affected and unaffected individuals mostly according to the carriership of MS-predisposing DR2 haplotype or its constituents and a subsequent pair comparison of phenotypic frequencies of distinct alleles of another gene of interest in subgroups of MS patients and controls. This kind of analysis found reliable associations of $\mathrm{MS}$ in subgroups of $D R B 1^{*} 15(2)$ (or $D Q B 1 * 0602)$-positive or negative individuals with the carriership of some alleles of genes coding TCR $\beta$ receptor [14], TGF $\beta 1$ [16], CTLA4 [13], ICAM-1 [19] and interleukin 4 receptor [18]. In our recent studies, we have extended this approach and stratified individuals according to any $D R B 1$ phenotypes. For $D R B 1 * 04$-positive individuals, associations of MS with CCR5 32 mutation [15] and with alleles of myelin basic protein $(M B P)$ gene [17] were found. The latter association was found also for $D R B 1 * 05$ positive individuals [17].

A novel nonparametric methodology used in this paper provides the capability to explore potential combinations of more than two allelic variants of polymorphic candi- 
Table 2: Phenotypic frequencies (carriership) of the three-allele combinations (trios) and their two-element subsets in Russian MS patients and healthy individuals

\begin{tabular}{|c|c|c|c|c|}
\hline Allelic combinations & MS patients, N (\%) & Controls, N (\%) & $p$-value $\#$ & OR $(95 \% \mathrm{Cl})^{\# \#}$ \\
\hline$-509 T G F \beta|* C, D R B I *| 8(3), C T L A 4 * G($ trio I)* & $5(5.3)$ & $0(0)$ & 0.0086 & $18.0(1.0-330)$ \\
\hline$-509 T G F \beta|* C, D R B I *| 8(3)$ & $5(4.4)$ & $2(0.7)$ & 0.029 & \\
\hline$-509 T G F \beta 1 * \mathrm{C}$, CTLA4*G & $63(61)$ & $102(58)$ & 0.61 & \\
\hline$D R B I * I 8(3), C T L A 4 * G$ & $5(3.0)$ & $2(1.1)$ & 0.26 & \\
\hline$-238 T N F * \mathrm{BI},-308 T N F * A 2, C T L A 4 * \mathrm{G}$ (trio 2$) * *$ & II (8.7) & $0(0)$ & 0.0033 & $17.4(1.1-300)$ \\
\hline$-238 T N F * \mathrm{BI},-308 T N F * \mathrm{~A} 2$ & $13(9.9)$ & $6(5.4)$ & 0.26 & \\
\hline$-238 T N F * B I, C T L A 4 * G$ & $38(30)$ & $15(17)$ & 0.036 & \\
\hline$-308 T N F^{*} \mathrm{~A} 2, \mathrm{CTLA4} * \mathrm{G}$ & $26(16)$ & $15(14)$ & 0.73 & \\
\hline
\end{tabular}

\footnotetext{
* 99 MS patients and I54 controls were genotyped at these polymorphic loci of TGF $\beta$ I, DRBI and CTLA4 genes.

** $126 \mathrm{MS}$ patients and 87 controls were genotyped at these polymorphic loci of TNF and CTLA4 genes.

\#p-values considered to be significant are given in bold face.

\#\# OR $(95 \% \mathrm{Cl})$ values are shown for significant $p$-values.
}

date genes. Two previously unknown tri-allelic combinations: $-509 T G F \beta 1{ }^{*} \mathrm{C}, \quad D R B 1^{*} 18(3), \quad C T L A 4^{*} \mathrm{G}$ and $238 T N F^{*} \mathrm{~B} 1,-308 T N F^{*} \mathrm{~A} 2, \mathrm{CTLA4}{ }^{*} \mathrm{G}$, which perfectly separate cases from controls in the present sample, were identified. Importantly, at least within our data set, nonoverlapping subgroups of individuals bearing predisposing trios 1 and 2 constitute about $5 \%$ and $9 \%$ of considered MS patients, respectively, and $0 \%$ of considered healthy controls (see Table 2). This suggests that carriership of these patterns might predict MS development. Due to the linkage disequilibrium of chromosomal loci, a genetic epidemiological approach cannot prove unambiguously that a disease-associated gene is causal. However, a biological role for the DRB1, CCR5, TGF $\beta 1, T N F$ and CTLA4 gene products in the pathogenesis of MS is plausible, and supports the idea that the genes are actual MS susceptibility genes.

Trios 1 and 2 have striking similarities that may determine their MS-predisposing properties due to dysregulation of inflammatory pathways by protein products encoded by their genes. First, both trios include the allele $\mathrm{G}$ of the gene for co-stimulatory molecule CTLA4, which is an important inhibitor of T-cell activation [39]. Carriers of the +49 CTLA $4{ }^{*} \mathrm{G}$ allele in exon 1 , coding for the peptide leader sequence, are characterized by a reduced CTLA4 inhibitory function [40], i.e. by impaired negative regulation of the immune response. Second, both trios include alleles of cytokine genes which promote inflammatory immune response owing to decreased level of antiinflammatory cytokine TGF $\beta 1$ (trio 1) or increased level of proinflammatory cytokine TNF (trio 2). Indeed, it is known that the circulating concentration of TGF $\beta 1$ is under genetic control, being lower in carriers of the promoter -509TGF $\beta 1{ }^{*} \mathrm{C}$ allele, in comparison with $509 T G F \beta 1{ }^{*}$ T allele [41]. The $-308 T N F^{*} A 2$ allele included in trio 2 is more actively transcribed than $-308 \mathrm{TNF}^{*} \mathrm{~A} 1$ [42]. The sequence of the promoter region of -
$238 T N^{*} \mathrm{~B} 1$, another trio 2 TNF allele, suggests that it is also associated with increased TNF expression [43]. In trio $1\left(-509 T G F \beta 1{ }^{*} \mathrm{C}, D R B 1{ }^{*} 18(3), C T L A 4{ }^{*} \mathrm{G}\right)$ carriers, a twohit repression of negative regulation of the immune response is coupled with a contribution of the HLA class II $D R B 1^{*} 18(3)$, which is not associated alone with MS (see Figure 2A). Characteristics of autoantigen presentation in MS by the products encoded by DRB1*18(3) have not been studied; however, it is clear that presence of this allele in trio 1 may be an important factor of the individual immune response regulation, supplementing effects provided by two other alleles of the trio.

Our results support the notion that genetic susceptibility to MS arises as a result of contribution of several predisposing alleles involved in the autoimmune inflammatory response. The nature of the interplay between the alleles in the trios remains unclear. If it arises as a result of a cumulative effect of multiple hits, these patterns provide a picture of small, individually insufficient changes combining to provide an overall significant response leading to predisposition to MS. However, this scenario does not exclude possible epistatic interactions of genes involved in the trios.

\section{Conclusion}

The results presented here provide the first identification of a combination of more than two alleles conferring a genetic predisposition to MS as a complex polygenic disease. The two newly identified trios perfectly separate cases from controls, at least in the present sample, as would occur in a classic monogenic dominant disease, where all observed carriers are patients. Because of sample size limitations, the result can only be considered as preliminary. However, the biological properties of the genes included in the identified trios suggest a coherent picture of dysregulation of inflammatory pathways, implying the validity of the MS-associated patterns and encouraging 
efforts required to replicate associations in independent data. The APSampler algorithm used to identify the predisposing patterns is highly efficient, as it requires only hours of computation time on a laptop computer for this data set, and is flexible, as it can handle incomplete genotypic information. The algorithm provides a valuable resource for the growing volume of polygenic diseaserelated genomic data, allowing efficient exploration of such data to identify genetic predisposition and potential therapeutic targets.

\section{Competing interests}

The author(s) declare that they have no competing interests.

\section{Authors' contributions}

OOF and MFO set up the initial formulation of the problem. OOF organized the interaction between the medical, genetic and algorithmic groups. OOF, AVF, GP and MFO wrote the manuscript. AVF and MFO conceived of and developed the algorithm and the software. ANB and EIG diagnosed MS and recruited patients. ANB, MAS and TVA recruited healthy controls. ANB, EIG and OOF selected the candidate genes. TVA, MAS, ADA, and OGK performed genotyping analysis. OGK, MAS and OOF interpreted the patterns identified by the algorithm. MAS, TVA and AVF applied the software to the genotyping database developed by TVA. GP provided expert statistical advice used to significantly improve the algorithm.

\section{Additional material}

\section{Additional File 1}

Additional Figure 1 - TNFa/TNFb haplotype frequencies in MS patients and controls. Haplotypes are designated in accordance with TNFa/TNFb allele names.

Click here for file

[http://www.biomedcentral.com/content/supplementary/14712350-7-63-S1.pdf]

\section{Additional File 2}

Additional Figure 2 - DRB1/TNFa haplotype frequencies in MS patients and controls. A: DRB1*01 -DRB1*03 alleles; B: DRB1*04DRB $1{ }^{*} 09$ alleles. Haplotypes are designated in accordance with DRB1/ TNFa allele names. Haplotypes with frequencies less than $0.5 \%$ both in MS patients and in controls are not shown.

Click here for file

[http://www.biomedcentral.com/content/supplementary/14712350-7-63-S2.pdf]

\section{Additional File 3}

Additional Figure 3 - TNF/LT haplotypes in MS patients and controls. A: TNF/LT haplotype frequencies in all MS patients and controls; haplotype designations and entering SNP alleles are shown below. B: Frequencies of extended haplotypes including DRB $1{ }^{*} 15$ (2) and different TNF/LT haplotypes in all MS patients and controls. Haplotypes are marked in accordance with DRB1 allele name and TNF/LT haplotype designation given in A. For better visualization, the same axis scales were used. Click here for file

[http://www.biomedcentral.com/content/supplementary/14712350-7-63-S3.pdf]

\section{Additional File 4}

Additional Table 1 - Phenotypic frequencies (\%) of SNP alleles in Russian MS patients and healthy individuals

Click here for file

[http://www.biomedcentral.com/content/supplementary/14712350-7-63-S4.pdf]

\section{Acknowledgements}

We thank Erica Golemis and Kenneth Morgan for very useful discussion and for advice. All authors from Russia thank Russian Foundation for Basic Research (05-04-48982-a and 04-04-4960 I-a). AVF thanks the Howard Hughes Medical Institute $(550056$ I0), the Ludwig Institute for Cancer Research (CRDF 12039), Russian Ministry of Science and Education (State Contract \# 02.434. I 1008) and Russian Academy of Sciences Presidium Program in Molecular and Cellular Biology. GP thanks NSF (DMS0342 I I) and $\mathrm{NCl}$ (CA06973). MFO thanks NCl (support under CCSG grant CA06927), the National Library of Medicine (LM008932), and the Pennsylvania Department of Health for support.

\section{References}

I. Hirschhorn JN, Daly MJ: Genome-wide association studies for common diseases and complex traits. Nat Rev Genet 2005, 6(2):95-108.

2. Thornton-Wells TA, Moore JH, Haines JL: Genetics, statistics and human disease: analytical retooling for complexity. Trends Genet 2004, 20( ( 2):640-647.

3. Threadgill DW, Hunter KW, Williams RW: Genetic dissection of complex and quantitative traits: from fantasy to reality via a community effort. Mamm Genome 2002, I3(4): 175-I 78.

4. Bomprezzi R, Kovanen PE, Martin R: New approaches to investigating heterogeneity in complex traits. J Med Genet 2003, 40(8):553-559.

5. Herrera BM, Ebers GC: Progress in deciphering the genetics of multiple sclerosis. Curr Opin Neurol 2003, I6(3):253-258.

6. Kalman B, Albert RH, Leist TP: Genetics of multiple sclerosis: determinants of autoimmunity and neurodegeneration. Autoimmunity 2002, 35(4):225-234.

7. Kenealy SJ, Babron MC, Bradford Y, Schnetz-Boutaud N, Haines JL, Rimmler JB, Schmidt S, Pericak-Vance MA, Barcellos LF, Lincoln RR, et al:: A second-generation genomic screen for multiple sclerosis. Am J Hum Genet 2004, 75(6): 1070- 1078.

8. Sawcer S, Ban M, Maranian M, Yeo TW, Compston A, Kirby A, Daly MJ, De Jager PL, Walsh E, Lander ES, et al.: A high-density screen for linkage in multiple sclerosis. Am J Hum Genet 2005, 77(3):454-467.

9. GAMES, Transatlantic Multiple Sclerosis Genetics Cooperative: A meta-analysis of whole genome linkage screens in multiple sclerosis. J Neuroimmunol 2003, I 43( I-2):39-46.

10. Kenealy SJ, Pericak-Vance MA, Haines JL: The genetic epidemiology of multiple sclerosis. J Neuroimmunol 2003, I43(I-2):7-12.

II. Risch NJ: Searching for genetic determinants in the new millennium. Nature 2000, 405(6788):847-856. 
12. Dyment DA, Ebers GC, Sadovnick AD: Genetics of multiple sclerosis. Lancet Neurol 2004, 3(2): I04-I I0.

13. Alizadeh M, Babron MC, Birebent B, Matsuda F, Quelvennec E, Liblau R, Cournu-Rebeix I, Momigliano-Richiardi P, Sequeiros J, Yaouanq J, et al.: Genetic interaction of CTLA-4 with HLA-DR I 5 in multiple sclerosis patients. Ann Neurol 2003, 54(I): I I9-122.

14. Dyment DA, Steckley JL, Morrison K, Willer CJ, Cader MZ, DeLuca GC, Sadovnick AD, Risch N, Ebers GC: TCR beta polymorphisms and multiple sclerosis. Genes Immun 2004, 5(5):337-342.

15. Favorova OO, Andreewski TV, Boiko AN, Sudomoina MA, Alekseenkov AD, Kulakova OG, Slanova AV, Gusev El: The chemokine receptor CCR5 deletion mutation is associated with MS in HLA-DR4-positive Russians. Neurology 2002, 59(10): 1652-1655.

16. Green AJ, Barcellos LF, Rimmler JB, Garcia ME, Caillier S, Lincoln RR, Bucher P, Pericak-Vance MA, Haines JL, Hauser SL, et al.: Sequence variation in the transforming growth factor-betal (TGFBI) gene and multiple sclerosis susceptibility. J Neuroimmunol $200 \mathrm{I}$, II6(I):II6-124.

17. Guerini FR, Ferrante P, Losciale L, Caputo D, Lombardi ML, Pirozzi G, Luongo V, Sudomoina MA, Andreewski TV, Alekseenkov AD, et al.: Myelin basic protein gene is associated with MS in DR4and DR5-positive Italians and Russians. Neurology 2003, 6I(4):520-526.

18. Mirel DB, Barcellos LF, Wang J, Hauser SL, Oksenberg JR, Erlich HA: Analysis of IL4R haplotypes in predisposition to multiple sclerosis. Genes Immun 2004, 5(2): |38-|4I.

19. Nejentsev S, Laaksonen M, Tienari PJ, Fernandez O, Cordell H, Ruutiainen J, Wikstrom J, Pastinen T, Kuokkanen S, Hillert J, et al.: Intercellular adhesion molecule-I K469E polymorphism: study of association with multiple sclerosis. Hum Immunol 2003, 64(3):345-349.

20. Favorov AV, Andreewski TV, Sudomoina MA, Favorova OO, Parmigiani G, Ochs MF: A Markov Chain Monte Carlo Technique for Identification of Combinations of Allelic Variants Underlying Complex Diseases. Genetics 2005, I7I(4):2II3-2I2I.

21. McDonald WI, Compston A, Edan G, Goodkin D, Hartung HP, Lublin FD, McFarland HF, Paty DW, Polman CH, Reingold SC, et al.: Recommended diagnostic criteria for multiple sclerosis: guidelines from the International Panel on the diagnosis of multiple sclerosis. Ann Neurol 200I, 50(I): |2I-I27.

22. Sudomoina MA, Boiko AN, Demina TL, Gusev El, Boldyreva MN, Trofimov D, Alekseev LP, Favorova OO: Connection of multiple sclerosis in the Russian population with alleles of the major histocompatibility complex DRB I gene. Mol Biol (Mosk) 1998, 32(2):29|-296.

23. Nedospasov SA, Udalova IA, Kuprash DV, Turetskaya RL: DNA sequence polymorphism at the human tumor necrosis factor (TNF) locus. Numerous TNF/lymphotoxin alleles tagged by two closely linked microsatellites in the upstream region of the lymphotoxin (TNF-beta) gene. J Immunol 1991, I 47(3): 1053-1059.

24. Gallagher G, Eskdale J, Oh HH, Richards SD, Campbell DA, Field M: Polymorphisms in the TNF gene cluster and MHC serotypes in the West of Scotland. Immunogenetics 1997, 45(3): I88-194.

25. He B, Navikas V, Lundahl J, Soderstrom M, Hillert J: Tumor necrosis factor alpha-308 alleles in multiple sclerosis and optic neuritis. J Neuroimmunol 1995, 63(2): 143-147.

26. GeneFisher [http://bibiserv.techfak.uni-bielefeld.de/genefisher]

27. Roth MP, Nogueira L, Coppin H, Clanet M, Clayton J, Cambon-Thomsen $A$ : Tumor necrosis factor polymorphism in multiple sclerosis: no additional association independent of HLA. J Neuroimmunol 1994, 5 I (I):93-99.

28. Cambien F, Ricard S, Troesch A, Mallet C, Generenaz L, Evans A, Arveiler D, Luc G, Ruidavets JB, Poirier O: Polymorphisms of the transforming growth factor-beta I gene in relation to myocardial infarction and blood pressure. The Etude CasTemoin de l'Infarctus du Myocarde (ECTIM) Study. Hypertension 1996, 28(5):88I-887.

29. Bignon JD, Fernandez-Vina MF: Technical Handbook: Twelfth International Histocombatibility Workshop and Conference. Paris: HLA et Me'decine; 1996.

30. Sandford AJ, Pare PD: Direct PCR of small genomic DNA fragments from serum. Biotechniques 1997, 23(5):890-892.

3I. Marron MP, Raffel LJ, Garchon HJ, Jacob CO, Serrano-Rios M, Martinez Larrad MT, Teng WP, Park Y, Zhang ZX, Goldstein DR, et al. Insulin-dependent diabetes mellitus (IDDM) is associated with CTLA4 polymorphisms in multiple ethnic groups. Hum Mol Genet 1997, 6(8): 1275-I282.

32. Robert C, Casella G: Monte Carlo Statistical Methods. New York: Springer Verlag; 1999.

33. Metropolis N, Rosenbluth A, Rosenbluth M, Teller A, Teller E: Equations of state calculations by fast computing machines. J Chem Phys 1953, 21:1087-1091.

34. Schneider S, Roessli D, Excoffier L: Arlequin: A software for population genetics data analysis. Ver 2.000. 2000 [http:// cmpg.unibe.ch/software/arlequin3/]. Genetics and Biometry Lab, Dept. of Anthropology, University of Geneva; Arlequin

35. Efron B, Tibshirani R, Storey JD, Tusher V: Empirical Bayes Analysis of a Microarray Experiment. J Am Statist Assoc 200I, 96(456): II5I-II60.

36. Boiko AN, Gusev El, Sudomoina MA, Alekseenkov AD, Kulakova OG Bikova OV, Maslova OI, Guseva MR, Boiko SY, Guseva ME, et al: Association and linkage of juvenile MS with HLA-DR2(15) in Russians. Neurology 2002, 58(4):658-660.

37. Gusev E, Sudomoina M, Boiko A, Deomina T, Favorova O: TNF gene polymorphisms: associations with multiple sclerosis susceptibility and severity. In Frontiers in multiple sclerosis Edited by: O A, H O. London: Martin Dunitz; 1997:35-4I.

38. de Jong BA, Huizinga TW, Zanelli E, Giphart MJ, Bollen EL, Uitdehaag $\mathrm{BM}$, Polman $\mathrm{CH}$, Westendorp RG: Evidence for additional genetic risk indicators of relapse-onset MS within the HLA region. Neurology 2002, 59(4):549-555.

39. Alegre ML, Frauwirth KA, Thompson CB: T-cell regulation by CD28 and CTLA-4. Nat Rev Immunol 200I, I(3):220-228.

40. Maurer M, Loserth S, Kolb-Maurer A, Ponath A, Wiese S, Kruse N, Rieckmann P: A polymorphism in the human cytotoxic T-lymphocyte antigen 4 (CTLA4) gene (exon I +49) alters T-cell activation. Immunogenetics 2002, 54(I): I-8.

4I. Grainger DJ, Heathcote K, Chiano M, Snieder H, Kemp PR, Metcalfe JC, Carter ND, Spector TD: Genetic control of the circulating concentration of transforming growth factor type betal. Hum Mol Genet 1999, 8(1):93-97.

42. Uboldi de Capei MU, Dametto E, Fasano ME, Rendine S, Curtoni ES Genotyping for cytokine polymorphisms: allele frequencies in the Italian population. Eur J Immunogenet 2003, 30(I):5-10

43. Grove J, Daly AK, Bassendine MF, Day CP: Association of a tumor necrosis factor promoter polymorphism with susceptibility to alcoholic steatohepatitis. Hepatology 1997, 26(I): I43-I 46.

44. Marsh SG, Albert ED, Bodmer WF, Bontrop RE, Dupont B, Erlich HA Geraghty DE, Hansen JA, Mach B, Mayr WR, et al:: Nomenclature for factors of the HLA system, 2002. Hum Immunol 2002, 63(12): $1213-1268$.

\section{Pre-publication history}

The pre-publication history for this paper can be accessed here:

\section{http://www.biomedcentral.com/1471-2350/7/63/prepub}

Publish with Bio Med Central and every scientist can read your work free of charge

"BioMed Central will be the most significant development for disseminating the results of biomedical research in our lifetime. "

Sir Paul Nurse, Cancer Research UK

Your research papers will be:

- available free of charge to the entire biomedical community

- peer reviewed and published immediately upon acceptance

- cited in PubMed and archived on PubMed Central

- yours - you keep the copyright
BioMedcentral 